\title{
Penggunaan Power Point Interaktif Dalam Kegiatan Bercerita Untuk Meningkatkan Kemampuan Berbicara Anak Di Masa Pandemik Covid-
}

19

\author{
Siti Kurniasih \\ Institut Agama Islam Negeri Metro, Indonesia \\ sitikurniasih@metrouniv.ac.id
}

\begin{abstract}
Abstrak
Berbicara merupakan kebutuhan dasar yang sangat penting harus di miliki manusia untuk berkomunikasi. Tujuan penelitian ini untuk meningkatkan kemampuan berbicara anak PAUD Irzahan usia 4-5 tahun melalui kegiatan bercerita menggunakan power point interaktif. Penelitian Tindakan digunakan sebagai jenis metode dalam penelitian ini yang dilaksanakan dalam dua siklus dengan lima kali pertemuan pada setiap siklus. Subjek penelitian adalah anak kelompok A berjumlah 10 orang anak. Instrumen yang digunakan adalah lembar observasi yang terdiri dari observasi aktivitas anak dengan menggunakan power point interaktif. Analisis data menggunakan data kuantitatif dan kualitatif. Analisis data kuantitatif dengan statistik deskriptif yaitu membandingkan hasil yang diperoleh dari siklus pertama dan siklus kedua. Sedangkan analisis data kualitatif dengan cara menganalisis data dari hasil catatan observasi dan wawancara selama penelitian dengan langkahlangkah reduksi data, display data dan verifikasi data. Hasil penelitian menunjukkan adanya peningkatan kemampuan berbicara anak melalui kegiatan bercerita menggunakan power point interaktif yang dapat dibuktikan rata-rata skor kemampuan berbicara pra-siklus $56,06 \%$, mengalami peningkatan pada siklus I sebesar $75,00 \%$ dan pada siklus II meningkat sebesar $80,30 \%$.
\end{abstract}

Kata Kunci: kemampuan berbicara; power point; bercerita

\section{Interactive Power Point In Storytelling Activities To Improve Children's Speaking Ability During The Covid-19 Pandemic}

\begin{abstract}
Speaking is a very important basic need that humans must have to communicate. The purpose of this study was to improve the speaking ability of PAUD Irzahan children aged 4-5 years through storytelling activities using powerpoints interactive. Action research is used as a type of method in this research which is carried out in two cycles with five meetings in each cycle. The research subjects were 10 children in group A. The instrument used is an observation sheet which consists of observing children's activities using powerpoints interactive. Data analysis used quantitative and qualitative data. Analysis of quantitative data with descriptive statistics is to compare the results obtained from the first cycle and the second cycle. While qualitative data analysis by analyzing data from the results of observation notes and interviews during the study with data reduction steps, data display and data verification. The results showed that there was an increase in children's speaking skills through storytelling activities using power points which could be proven by the average pre-cycle speaking ability score of $56.06 \%$, an increase in the first cycle of $75.00 \%$ and in the second cycle it increased by 80 , $30 \%$.
\end{abstract}

Keywords: speaking ability; power point; storytelling 


\section{PENDAHULUAN}

Anak usia dini berada dalam fase di mana perkembangan otak berkembang dengan optimal (Muhiyatul Huliyah, 2016). Perkembangan otak dapat memengaruhi aspek-aspek perkembangan pada anak usia dini. Salah satu aspek perkembangan yang harus dioptimalkan sejak dini yaitu perkembangan bahasa anak (Aprinawati, 2017) . Perkembangan bahasa anak membutuhkan peran lingkungan untuk membantu anak mengoptimalkan kemampuannya. Saat anak usia dini sudah mulai bersekolah peran lingkungan tidak hanya di rumah melainkan di sekolah juga. Peran lingkungan di rumah lebih besar kuantitas waktu bersama anak dibandingkan di sekolah. Dengan banyaknya waktu anak di rumah selama pembelajaran dalam jaringan ini harus diimbangi dengan kualitas belajar anak di rumah bersama orangtua anak.

Perkembangan bahasa anak sangat penting dioptimalkan karena bahasa sebagai alat komunikasi yang utama bagi manusia (Sintia et al., 2019). Bahasa merupakan sarana untuk mengekspresikan apa yang ada dalam pikiran, dan memberikan sumbangan yang besar dalam perkembangan anak. Berdasarkan hasil observasi kemampuan berbicara anak TK A di PAUD Irzahan yang dilakukan saat pra penelitian. Skor rata-rata kemampuan berbicara anak TK A sebesar 56,06\%. Hasil individu pada setiap anak menunjukkan adanya anak DP yang memperoleh skor terendah sebesar 41,67\% dengan kategori kemampuan berbicara anak belum berkembang, dan RM memperoleh skor tertinggi yaitu 70,83\% kemampuan berbicara anak berkembang sesuai harapan. Hasil observasi dapat dipaparkan bahwa pembelajaran daring atau online membutuhkan orangtua dalam mengembangkan kemampuan berbicara anak. Keterlibatan orangtua dapat memengaruhi perkembangan bahasa anak contohnya kualitas dan kuantitas waktu untuk mendukung anak dalam proses perkembangan berbicara anak. Oleh sebab itu perlunya peran PAUD dalam membuat metode pembelajaran yang mudah diaplikasikan orangtua mengingat waktu yang diberikan kepada anak oleh setiap orangtua berbeda-beda. Dari segi profesi orangtua menentukan waktu yang dapat diberikan kepada anak juga berbeda sehingga penelitian ini diperlukan untuk membuat metode pembelajaran yang sesuai dengan usia dan tahapan perkembangan anak di masa pandemik 
ini. Peranan guru benar-benar dituntut untuk lebih kreatif dalam memfasilitasi anak yang khususnya dalam meningkatkan kemampuan berbicara.

Pada penelitian ini, peneliti akan menggunakan suatu metode guna meningkatkan kemampuan berbicara anak yaitu bercerita menggunakan power point interaktif. Bercerita merupakan salah satu keterampilan yang dapat mengembangkan kemampuan anak untuk berkomunikasi dan berimajinatif baik sebagai pendengar ataupun pendongeng. Penelitian ini menggunakan metode power point yang memberikan kesempatan kepada anak untuk mengeksplorasi kemampuannya dalam berbicara.. Media power point interaktif yang didesain dengan menarik membuat minat dan motivasi anak untuk belajar semakin tinggi ditambahkan dengan suasana yang menyenangkan dalam kegiatan pembelajaran.

Bahasa sebagai alat komunikasi. Bentuk komunikasi tersebut mencakup lisan, tulisan, bahasa melalui isyarat, bahasa melalui gerakan tubuh, dan ekspresi yang terlihat pada wajah contohnya wajah pantonim dalam aspek seni rupa. Perkembangan bahasa pada anak usia dini dimulai pada saat tangisan pertama anak hingga anak mulai dapat berbicara. Oleh sebab itu pentingnya perkembangan bahasa dan stimulasinya sejak dini agar anak dapat menjalin hubungan sosial yang baik di masa akan datang.

Pada saat anak dilahirkan, tangisan pertama itulah mulainya perkembangan bahasa anak hingga anak mampu berbicara. Perkembangan pada anak usia dini mencakup dua tahapan yaitu tahap pralinguistik dan tahap linguistik. Tahap pralinguistik ditandai pada fase bayi berupa ekspresi-ekspresi tertentu misalnya menangis, tertawa, dan berbagai ekspresi yang menandakan suatu komunikasi yang bayi sampaikan ketika bayi merasa lapar, haus, ingin digendong, tidur, dan kondisi yang menandakan ketidaknyamanan bayi. Bahasa bayi ketika merasa tidak nyaman contohnya saat anak mengompol, sedang buang air besar, tergigit serangga, atau sedang merasakan sakit. Seiring berjalannya waktu, tahapan ini akan meningkat hingga anak mampu mengucapkan penggalan kata, kata-kata sederhana walaupun belum terdengar jelas dan belum dipahami. Tingkatan tahapan selanjutya yaitu tahap lingusitik, pada tahap ini kata-kata yang diucapkan anak sudah mulai dipahami hingga anak dapat menyusun kata-kata menjadi sebuah kalimat dari kalimat yang belum dipahami hingga sudah dapat dipahami. 
Kemampuan berbahasa anak didapatkan secara menakjubkan sejak usia kelahiran sampai usia 6 tahun, anak tidak pernah pernah belajar bahasa, apalagi kosakata secara khusus. Akan tetapi diakhir masa usia dininya, rata-rata anak sudah memiliki atau menyimpan lebih dari 14.000 kosakata. Hal ini adalah angka yang sangat menakjubkan untuk anak usia dini. Pada dasarnya bahasa yaitu rangkaianinbunyi yang melambangkan pikiran, perasaan, dan sikap pada manusia

Bahasa merupakan alat untuk berpikir, berkomunikasi serta mengekpresikan diri. Keterampilan pada bahasa juga sangat berpengaruh dalam upaya pembentukan konsep, pemecahan masalah dan informasi. Dengan bahasa pula kita dapat memahami komunikasii fikiran serta perasaan. Perkembangan bahasa yaitu meningkatkan kemampuan penguasaan alat dalam berkomunikasi baik dengan tertulis, lisan, maupun menggunakan isyarat dan tanda-tanda. Semakin anak tumbuh serta berkembang mulai dari tingkat sederhana menuju ke bahasa yang lebih kompleks. Anak mempelajari bahasa sama halnya dengan belajar halhal yang lainnya, meniru kemudian mengulang adalah hasil awal pembelajaran bahasa. Kemudian anak akan menambahkan kata demi kata dan menirukan berbagai bunyi-bunyian yang didengarnya (Mursid, 2015).

Perkembangan berbicara pada anak usia dini merupakan salah satu aspek terpenting dalam proses awal sampai dengan akhir pertumbuhannya. Mengembangkan berbicara pada anak harus dilakukan sejak usianya masih dini. Karena pada usia inilah anak mudah menangkap dan mempelajari banyak hal. Seiring meningkatnya usia pada anak maka perkembangan berbicaranya akan semakin meningkat. Dengan berbicara maka anak dapat melakukan komunikasi dengan orang lain, mengemukakan pendapat, menyampaikan perasaan, menuangkan ide dalam bentuk lisan maupun tulisan, berbicara isyarat, ekspresi wajah, dan berbicara gerak tubuh. Berbicara merupakan segala bentuk hal yang dapat dikomunikasikan guna menyampaikan pikiran dan perasaan untuk menyampaikan arti kepada orang lain. Oleh sebab itu, perkembangan berbicara anak sudah dimulai sejaktangisan pertama anak dilahirkan. Guru dan orangtua mempunyai peran penting dalam mengembangkan berbicara sejak anak usia dini. Untuk meningkatkan kemampuan bicara 
anak TK dapat melalui kegiatan-kegiatan bercerita menggunakan digital. (Karlina et al., 2018). Karakteristik kemampuan berbicara anak sebagai berikut:

Karakteristik Berbicara Anak Usia 4 Tahun

1. Anak mampu mengucapkan kalimat yang lebih kompleks

2. Anak mampu berbicara dengan kalimat yang sudah dipahami orang dewasa

3. Anak sudah bisa mengubah intonasi suara bisa semakin keras dan lembut sesuai situasi yang ada di sekitar anak

4. Anak sudah mampu menyebutkan nama dengan lengkap, nama orangtua, dan alamat rumah

5. Anak sudah dapat menjawab pertanyaan dengan tepat

Karakteristik Berbicara Anak Usia 5 tahun

1. Menceritakan kembali cerita yang didengarkan

2. Anak mampu menyebutkan minimal empat warna

3. Mengucapkan kalimat yang lebih kompleks hingga lebih dari tujuh kata

4. Anak mampu mengucapkan kalimat yang seluruhnya mampu dimengerti orang dewasa

5. Anak suka bercanda dan membuat lelucon seru dengan teman sebayanya

6. Jika ditanya mengenai kegunaan suatu benda disekitar anak, anak dapat menjawab tepat sesuai dengan pertanyaan

7. Menguasai 1500 kosakata atau lebih

Pembelajaran yang dilakukan orangtua melalui kegiatan mendongeng dimulai dari mendengarkan, menerima informasi, kemudian anak mampu berbicara sehingga kemampuan anak dalam berbicara meningkat (Sablez \& Pransiska, 2020). Kegiatan bercerita dapat memberikan kesempatan anak untuk menyimak dan berbicara. Mendongeng bernilai positif untuk mengembangkan kecerdasan verbal linguistik diawali dengan kegiatan mengenal kosakata baru, memahami alur dari sebuah cerita hingga menjadi terampil dalam berbicara (Rosalina et al., 2010). Saat bercerita, Anak terlatih dalam pengucapan bunyi kata, menyampaikan pikiran, dan anak mampu mengekspresikan perasaaannya (Hodijah, 2016). Proses bercerita kemudian anak diberikan kesempatan menceritakan isi cerita pada anak usia 4-5 tahun memberikan kesempatan anak untuk dapat meningkatkan kemampuan bahasa anak (Fauziddin, 2017). Kegiatan mendongeng dengan menggunakan buku cerita bergambar yang menarik dapat memotivasi minat anak dalam berbicara. Buku cerita bergambar dinyatakan memenuhi standar efektifitas dalam meningkatkan keterampilan berbicara anak usia 4-5 tahun.(Sholiha et al., 2021).Anak akan menambah kosakata setelah mendengar cerita, anak melakukan serangkaian aktivitas kognisi dan afeksi yang rumit dari fakta cerita seperti nama, 
tempat, dan sifat dalam tokoh cerita, sifat tokoh. Kiat-kiat dalam mengembangkan bahasa anak sejak usia dini mencakup (Madyawati, 2017):

1. Mengenalkan dan mendengarkan lagu yang mencerminkan tentang anak-anak,

2. Bermain tebak kata,

3. Bermain peran,

4. Menstimulus bahasa sejak bayi dengan mengajaknya berbibacara,

5. Membawakan cerita atau mendongeng sesuai dengan keadaan sekitar,

6. Berdiskusi tentang keadaan disekitar anak,

7. Memperkaya kosakata dan membuat pantun atau puisi sederhana.

Bercerita merupakan salah satu metode pendidikan yang baik, dan mudah dilakukan tanpa mengeluarkan banyak biaya, dan seringkali dilupakan oleh mayoritas orang tua pada masa sekarang ini, dengan alasan karena sedikitnya waktu yang mereka miliki, dan anakanak lebih menyukai bermain game di handphone. Dengan demikian diperlukan inovasi kegiatan pembelajaran mengikuti perkembangan zaman yang semakin meningkat teknologi informasi yaitu merancang kegiatan bercerita menggunakan handphone atau laptop dengan aplikasi microsoft power point.

Pembelajaran online atau yang dikenal dengan sebutan pembelajaran dalam jaringan (daring) pada masa pandemik ini keterlibatan orangtua sangat penting dalam mengembangkan aspek perkembangan dan dengan menjalin komunikasi efektif dengan guru di sekolah. Orangtua memiliki peranan dalam menjalin komunikasi intens dengan anak dan bermain dengan anak (Latif, 2013). Orangtua sangat dibutuhkan anak dalam memberikan fasilitasi dan membantu anak dalam pembelajaran daring. Orangtua harus mampu menciptakan lingkungan kondusif bagi anak untuk belajar, berdiskusi, bertanya, dan membantu anak mengenali dirinya. Pembelajaran daring menciptakan kelekatan dengan orangtua dan terciptanya suasana diskusi bersama dapat membantu anak mengembangkan kosakata anak dan kelancaran dalam berbicara.

Pembelajaran di masa pandemik ini menggunakan pembelajaran online sehingga membutuhkan dukungan orangtua dan sarana prasarana yang memadai, selain itu peranan orangtua dalam menguasai cara penggunaan teknologi informasi juga sangat penting. Pembelajaran online di masa pandemik ini mendominasi kegiatan anak dengan memberikan penugasan kepada peserta didik, banyaknya pendidik yang menginginkan pembelajaran tatap 
muka karena tidak semua orangtua atau wali murid memiliki HP dan Laptop serta cara pengunaannya dalam pembelajaran online (Nurdin \& Anhusadar, 2020). Power point merupakan aplikasi yang mudah untuk dibuat dalam pembelajaran dan menarik anak dengan pilihan desain dan warna sesuai dunia anak.

Penggunaan aplikasi Microsoft Power point dalam bentuk cerita bergambar membuat anak merasa tertarik untuk mendengarkan dan melihat cerita dan anak juga mudah memahami pembelajaran menggunakan Power Point (Luqman et al., 2021). Pembelajaran di masa pandemik ini membutuhkan media yang dapat merangsang motivasi anak untuk belajar. Media yang didalamnya terintegrasi melalui media foto, teks, poster, video, dan model problem based learning. Media power point yang bersifat multimedia merupakan solusi dalam mengatasi permasalahan pemberlajaran di masa pandemik ini (Purwanto \& W, 2016). Power point digunakan sebagai media yang sangat efektif mendukung pembelajaran interaktif melalui online. Penggunaan power point menimbulkan ketertarikan dan respon positif belajar oleh peserta didik. power point dapat meningkatkan motivasi belajar anak, membuat suasana menyenangkan dan tidak menjadikan kegiatan yang membosankan, meningkatkan antusiasme, materi pembelajaran lebih mudah diingat kembali.

Penggunaan media power point ini menjadikan pembelajaran yang lebih interaktif karena menjalin komunikasi dua arah antara pendidik dan peserta didik (Munasti, 2021). Pembelajaran online menjadi solusi efektif untuk mengaktifkan kelas meskipun pembelajaran tatap muka belum dapat dilaksanakan di sekolah mengingat waktu dan tempat menjadi beresiko pada masa pandemik ini. Pembelajaran online tetap harus melihat kondisi lingkungan dan karakteristik sekolah juga kemampuan orangtua dalam memberikan fasilitas pembelajaran online kepada peserta didik (Herliandry et al., 2020). Permainan bahasa menggunakan media power point dapat menstimulasi keterampilan berbicara anak karena anak terstimulasi untuk mengembangkan pengucapan anak, menambah kosakata, anak diberikan kesempatan menceritakan kembali cerita (Wibowo \& Suyadi, 2021)

Perkembangan bicara anak dapat terstimulasi oleh guru dengan memanfaatkan media power point. Power point digunakan untuk mempermudah guru dalam menyiapkan materi. Kegiatan pembelajaran menggunakan power point dapat membuat suasana pembelajaran 
yang menyenangkan untuk anak dan pembelajaran bahasa anak melalui daring menjadi lebih mudah(Armelia Nungki Nurbani \& Natalia Christina Sugiyanto, 2021). Berdasarkan pemaparan teori dan hasil observasi maka dibutuhkan media pembelajaran yang mudah, interaktif, dan inovatif dalam penggunaannya dengan kegiatan yang menyenangkan sesuai usia dan tahapan perkembangan anak demi tercapainya tujuan pembelajaran.

\section{METODE PENELITIAN}

Penelitian ini menggunakan metode yaitu penelitian tindakan. Penelitian tindakan ini menggunakan model Kemmis dan Taggart. Penelitian tindakan ini melalui tahapan yaitu perencanaan (planning), tindakan (acting) dan pengamatan (observing), serta refleksi (reflecting). Penelitian dilakukan sebanyak 2 siklus dengan jumlah pertemuan sebanyak 10 pertemuan. Pada tahap perencanaan, peneliti berkolaborasi dengan guru dan orangtua selama pembelajaran daring, kemudian membuat rencana pembelajaran dengan metode pembelajaran bercerita. Pada tahapan tindakan peran guru dan orangtua dalam mendukung metode pembelajaran bercerita yang diberikan kepada anak. Pada tahap pengamatan peneliti berkolaborasi dengan guru dan orangtua dalam melakukan pengamatan proses perkembangan berbicara anak melalui bercerita. Tahap selanjutnya yaitu refleksi untuk melihat asesmen perkembangan berbicara anak, yang mana hasilnya akan diobervasi apakah sudah sesuai dengan tujuan penelitian atau diperlukan tindakan untuk siklus selanjutnya. Penelitian ini menggunakan teknik analisis data kualitatif. Tenik analisis data dimulai dari data reduction, data display, data conclusing drawing/verification. Keberhasilan metode dalam penelitian ini melihat tingkat keberhasilan sebesar $70 \%$ dari keseluruhan indikator. Pengumpulan data penelitian dilakukan di PAUD Irzahan Bandar Lampung pada kelompok A dengan jumlah peserta didik 11 anak.

\section{HASIL DAN PEMBAHASAN}

\section{A. Hasil}

Hasil penelitian kemampuan berbicara anak menunjukkan peningkatan dari hasil observasi hingga siklus kedua. Ada empat kategori penilaian perkembangan anak yaitu 
Belum Berkembang (BB), Mulai Berkembang (MB), BSH (Berkembang Sesuai Harapan), dan BSB (Berkembang Sangat Baik). Berikut data observasi kemampuan berbicara anak sebelum penelitian:

Tabel 1. Data Observasi Pra Siklus Kemampuan Berbicara Anak

\begin{tabular}{rlcc}
\hline No & Nama anak & Persentase (\%) & \multicolumn{2}{c}{ Kategori } \\
\hline $\mathbf{1}$ & AHS & $62,50 \%$ & MB \\
$\mathbf{2}$ & APM & $54,17 \%$ & MB \\
$\mathbf{3}$ & CAM & $58,33 \%$ & MB \\
$\mathbf{4}$ & DP & $41,67 \%$ & BB \\
$\mathbf{5}$ & Fr & $58,33 \%$ & MB \\
$\mathbf{6}$ & KPR & $45,83 \%$ & BB \\
$\mathbf{7}$ & KA & $62,50 \%$ & MB \\
$\mathbf{8}$ & MR & $62,50 \%$ & MB \\
$\mathbf{9}$ & MAK & $54,17 \%$ & MB \\
$\mathbf{1 0}$ & MRA & $45,83 \%$ & BB \\
$\mathbf{1 1}$ & RM & $70,83 \%$ & BSH \\
Rata-rata kelas & $\mathbf{5 6 , 0 6 \%}$ & MB \\
\hline
\end{tabular}

Tabel di atas menunjukkan hasil kemampuan berbicara anak kelompok A yang dilakukan pada saat pra penelitian. Skor rata-rata kemampuan berbicara anak kelompok A sebesar $56,06 \%$. Hasil individu pada setiap anak menunjukkan adanya anak DP yang memperoleh skor terendah sebesar 41,67\%, dan RM memperoleh skor tertinggi yaitu 70,83\%. Hasil pra penelitian menggambarkan butuhnya metode pembelajaran yang disesuaikan dengan kondisi pembelajaran saat pandemik karena kemampuan berbicara anak masih terkategori mulai berkembang.

Hal tersebut diperkuat dari hasil pegamatan yang dilakukan peneliti yaitu sekolah menggunakan Whatsapp Group hanya untuk mengirimkan tugas dan mengirimkan lembar kerja ke grup kemudian orangtua mengirimkan kembali tugas yang telah diselesaikan. Dari pengamatan tersebut memperlihatkan hanya aspek perkembangan kognitif dan motorik yang lebih banyak terstimulasi dengan kegiatan yang sama setiap minggunya. Hasil tugas yang diberikan kepada guru juga terlihat sangat rapi sehingga terlihat peran orangtua dalam menyelesaikan tugas lebih dominan dibandingkan anak yang mengerjakannya sendiri. 
Hasil penelitian siklus I mengalami peningkatan kemampuan berbicara anak yang dapat dilihat dari data penelitian di bawah ini:

Tabel 2. Data Kemampuan Berbicara Anak Pada Siklus I

\begin{tabular}{rlrcl}
\hline No & Nama & Persentase (\%) & Kategori & Keterangan \\
\hline $\mathbf{1}$ & AHS & $79,17 \%$ & BSH & Meningkat dan Sudah Mencapai target \\
$\mathbf{2}$ & APM & $75,00 \%$ & BSH & Meningkat dan Sudah Mencapai target \\
$\mathbf{3}$ & CAM & $79,17 \%$ & BSH & Meningkat dan Sudah Mencapai target \\
$\mathbf{4}$ & DP & $62,50 \%$ & BB & Meningkat tetapi Belum Mencapai target \\
$\mathbf{5}$ & Fr & $79,17 \%$ & BSH & Meningkat dan Sudah Mencapai target \\
$\mathbf{6}$ & KPR & $66,67 \%$ & BB & Meningkat tetapi Belum Mencapai target \\
$\mathbf{7}$ & KA & $83,33 \%$ & BSH & Meningkat dan Sudah Mencapai target \\
$\mathbf{8}$ & MR & $79,17 \%$ & BSH & Meningkat dan Sudah Mencapai target \\
$\mathbf{9}$ & MAK & $70,83 \%$ & BSH & Meningkat dan Sudah Mencapai target \\
$\mathbf{1 0}$ & MRA & $62,50 \%$ & BB & Meningkat tetapi Belum Mencapai target \\
$\mathbf{1 1}$ & RM & $87,50 \%$ & BSB & Meningkat dan Sudah Mencapai target \\
Rata-rata & kelas & $\mathbf{7 5 , 0 0 \%}$ & BSH & Meningkat dan Sudah Mencapai target \\
\hline
\end{tabular}

Tabel di atas menunjukkan hasil kemampuan berbicara anak kelompok A yang dilakukan pada saat penelitian siklus pertama. Skor rata-rata kemampuan berbicara anak kelompok A sebesar 75,00\%. Hasil individu pada setiap anak menunjukkan adanya anak DP dan MRA yang memperoleh skor terendah skor terendah 62,50\% dan RM memperoleh skor tertinggi yaitu $87,50 \%$. Hasil siklus pertama menggambarkan dengan kegiatan bercerita menggunakan power point interaktif dapat meningkatkan kemampuan berbicara. Seluruh anak mengalami peningkatan kemampuan berbicara. Pada siklus pertama ini masih adanya tiga anak yang sudah meningkat kemampuan berbicaranya namun masuk dalam kategori mulai berkembang dan belum mencapai target sebesar $70 \%$. Hal tersebut diperkuat dari hasil pengamatan bahwa dukungan orangtua dalam menggunakan aplikasi dan meluang waktu untuk anak sangat berpengaruh dalam proses belajar secara online, dan faktor bawaan (keturunan), serta gaya belajar anak juga berbeda-beda.

Pada siklus kedua, guru melakukan koordinasi secara intens dengan orangtua terkait keterlibatan orangtua di rumah terhadap proses pembelajaran online, kemudian power point 
interaktif dirancang dengan desain yang dapat memberikan kesempatan anak untuk ikut memilih isi dalam cerita menggunakan power Point, kemudian anak diberikan kesempatan untuk memberikan pendapat atas pilihan isi cerita lalu di akhir cerita anak diberikan kesempatan untuk menceritakan kembali isi dari cerita di dalam power point tersebut. Berikut data siklus kedua kemampuan berbicara anak:

Tabel 3. Data Kemampuan Berbicara Anak Pada Siklus II

\begin{tabular}{|c|c|c|c|c|}
\hline No & Nama & Persentase (\%) & Kategori & Keterangan \\
\hline 1 & AHS & $83,33 \%$ & BSH & $\begin{array}{l}\text { Meningkat dan Sudah Mencapai } \\
\text { target }\end{array}$ \\
\hline 2 & APM & $79,17 \%$ & $\mathrm{BSH}$ & $\begin{array}{l}\text { Meningkat dan Sudah Mencapai } \\
\text { target }\end{array}$ \\
\hline 3 & CAM & $83,33 \%$ & $\mathrm{BSH}$ & $\begin{array}{l}\text { Meningkat dan Sudah Mencapai } \\
\text { target }\end{array}$ \\
\hline 4 & DP & $70,83 \%$ & BSH & $\begin{array}{l}\text { Meningkat dan Sudah Mencapai } \\
\text { target }\end{array}$ \\
\hline 5 & $\mathrm{Fr}$ & $83,33 \%$ & $\mathrm{BSH}$ & $\begin{array}{l}\text { Meningkat dan Sudah Mencapai } \\
\text { target }\end{array}$ \\
\hline 6 & KPR & $75,00 \%$ & $\mathrm{BSH}$ & $\begin{array}{l}\text { Meningkat dan Sudah Mencapai } \\
\text { target }\end{array}$ \\
\hline 7 & KA & $87,50 \%$ & BSB & $\begin{array}{l}\text { Meningkat dan Sudah Mencapai } \\
\text { target }\end{array}$ \\
\hline 8 & MR & $83,33 \%$ & BSH & $\begin{array}{l}\text { Meningkat dan Sudah Mencapai } \\
\text { target }\end{array}$ \\
\hline 9 & MAK & $75,00 \%$ & $\mathrm{BSH}$ & $\begin{array}{l}\text { Meningkat dan Sudah Mencapai } \\
\text { target }\end{array}$ \\
\hline 10 & MRA & $70,83 \%$ & $\mathrm{BSH}$ & $\begin{array}{l}\text { Meningkat dan Sudah Mencapai } \\
\text { target }\end{array}$ \\
\hline 11 & $\mathrm{RM}$ & $83,33 \%$ & BSH & $\begin{array}{l}\text { Meningkat dan Sudah Mencapai } \\
\text { target }\end{array}$ \\
\hline \multicolumn{2}{|c|}{ Rata-rata kelas } & $80,30 \%$ & BSH & $\begin{array}{l}\text { Meningkat dan Sudah Mencapai } \\
\text { target }\end{array}$ \\
\hline
\end{tabular}

Tabel di atas menunjukkan hasil kemampuan berbicara anak kelompok A yang dilakukan pada saat penelitian siklus kedua. Skor rata-rata kemampuan berbicara anak kelompok A sebesar 80,30 \%. Hasil individu pada setiap anak menunjukkan seluruh anak masuk dalam kategori berkembang sesuai harapan dan berkembang sangat baik. Berdasarkan data dari pra penelitian sampai siklus kedua menunjukkan kemampuan berbicara anak usia 4-5 tahun mengalami peningkatan. Hal ini membuktikan bahwa penggunaan media power 
point interaktif dapat meningkatkan kemampuan berbicara anak dalam pembelajaran online di masa pandemik.

Pelaksanaan bercerita sudah sering dilakukan namun dalam pembelajaran ini kegiatan bercerita dilakukan dengan memanfaatkan media power point interaktif. Kegiatan interaktif dan inovatif harus diwujudkan demi berlangsung kegiatan pembelajaran secara online di masa pandemik tetap berjalan dan tujuan pembelajaran dapat tercapai dalam mengembangkan aspek perkembangan anak khususnya berbicara. Media inovatif juga harus didukung dengan isi cerita yang menstimulasi aktivitas anak dalam penggunaan power point. Anak tidak hanya diam melihat dan mendengarkan orangtua membacakan cerita namun pembuatan media power point juga dirancang khusus agar anak bisa memilih isi cerita. Kegiatan tersebut membuat anak lebih dapat mengekplorasi kegiatan pembelajaran dan mengembangkan aspek berbicara anak. Penggunaan media power point dengan isi cerita yang inovatif. Peneliti berkolaborasi dengan guru dan orangtua menyajikan isi cerita yang berkaitan dengan dunia anak dengan memberikan kesan perasaan yang menyenangkan dan memperhatikan minat anak dalam bercerita. Pelaksanaan kegiatan bercerita dilakukan dengan suasana bermain dan menyenangkan.

Kegiatan bercerita menggunakan media power point dilakukan dengan tahapan sebagai berikut:

1. Membuat perencanaan pembelajaran harian sesuai tujuan pembelajaran

2. Membuat desain pembelajaran menggunakan power point interaktif yang inovatif

3. Membuat isi cerita dalam power point interaktif sesuai karakteristik anak usia 4-5 tahun yang terarah, jelas, dan menyenangkan

4. Menggunakan musik dalam cerita power point agar menarik perhatian anak

5. Sosialisasi penggunaan power point dalam kegiatan bercerita bersama guru dan orangtua

6. Pelaksanaan kegiatan pembelajaran dilakukan online bersama orangtua atau wali murid dengan tetap menjalin komunikasi dengan guru di sekolah

7. Anak diberikan kesempatan untuk memilih isi cerita, berdiskusi, dan menceritakan kembali cerita yang sudah anak lihat dan dengarkan.

Berdasarkan hasil dari penelitian memberikan gambaran bahwa peningkatan kemampuan berbicara anak dengan pembelajaran online di masa pandemik tetap bisa dioptimalkan melalui pembelajaran yang inovatif dan interaktif contohnya menggunakan 
aplikasi Microsoft Power Point. Metode dan media yang digunakan sesuai karakteristik usia dan tahapan perkembangan, dunia anak yaitu dunia bermain, serta gaya belajar anak yang berbeda-beda. Kegiatan bercerita juga menambahkan pengetahuan anak dan kemampuan anak berbicara. Kegiatan bercerita menggunakan power point juga memberikan kesempatan anak untuk memperoleh informasi, mengungkapkan pikiran, bertanya, dan memberikan tanggapan pada saat bercerita maupun setelah kegiatan bercerita selesai dilakukan bersama orangtua.

\section{B. Pembahasan}

Peran guru sangat penting dalam meningkatkan kemampuan berbicara anak secara maksimal dengan memberikan stimulasi pada proses pembelajaran di sekolah. Dan orangtua juga berperan penting dalam pembelajaran online sebagai fasilitator dan motivator anak di rumah (Anggraeni et al., 2021). Anak akan tumbuh dan berkembang menjadi pribadi yang bahagia dan lebih baik melalui berkomunikasi dengan lingkungan, serta bersedia memberi dan menerima segala hal yang terjadi dengan lingkungan (Jailani, 2014).

Peningkatan kemampuan berbicara anak usia dini di PAUD Irzahan terstimulasi melalui kegiatan bercerita dengan kolaborasi bersama orangtua. Media yang digunakan menggunakan power point dalam pembelajaran online yang dapat digunakan secara fleksibel baik oleh guru maupun orangtua. Kegiatan pembelajaran diawali dengan berdoa terlebih dahulu sesuai rencana pembelajaran harian untuk melatih kemampuan berbicara anak. Anak dapat menjawab pertanyaan yang diajukan oleh orangtua dan guru dan dengan adanya diskusi berperan penting untuk anak di PAUD Irzahan memahami kembali pesan dari cerita yang dibawakan oleh orangtua dan guru juga dapat mengetahui pengetahuan anak terkait materi, dengan adanya diskusi maka anak berkesempatan untuk menanyakan dan menyampaikan isi cerita kembali kepada anak untuk mengetahui sejauh mana pemahaman anak terkait isi cerita. Dalam penyampaian materi bercerita kepada anak dengan memperlihatkan power point yang sudah dibagikan oleh guru. Pelaksanaan kegiatan aktif mersespon dan mengungkapkan apa yang diketahui oleh anak tentang cerita yang sudah dibacakan oleh orangtua. Pada akhir kegiatan orangtua akan mengajak atau memberikan kesempatan tanya jawab tentang apa yang telah dilakukan pada pembelajaran hari itu. Kemudian guru meminta video ketika anak 
menyampaikan kembali isi cerita yang telah orangtua ceritakan. Hasil video yang diberikan orangtua menjadi salah satu bentuk asesmen terhadap kemampuan berbicara anak usia 4-5 tahun di PAUD Irzahan.

Optimalnya kolaborasi guru, dan orangtua, serta metode yang tepat dalam proses pembelajaran dapat meningkatkan kemampuan berbicara anak. Pada penelitian ini kemampuan berbicara anak tercapai dengan sangat baik dari keseluruhan indikator sebesar $80,30 \%$ sesuai dengan kriteria keberhasilan yang sudah ditetapkan. Indikator pencapaian kemampuan berbicara anak usia 4-5 tahun meliputi: Anak mampu mengucapkan kalimat yang lebih kompleks lebih dari lima kata, Anak mampu berbicara dengan kalimat yang sudah dipahami orang dewasa, Anak sudah bisa mengubah intonasi suara bisa semakin keras dan lembut sesuai situasi yang ada di sekitar anak, Anak mampu memberikan pertanyaan, Anak sudah dapat menjawab pertanyaan dengan tepat, dan anak mampu menceritakan kembali cerita yang didengarkan.

\section{SIMPULAN DAN SARAN}

Kemampuan anak dalam berbicara memiliki peranan penting untuk mendukung aspek perkembangan lainnya. Dukungan lingkungan untuk menstimulasi perkembangan berbicara anak diperlukan agar kemampuan berbicara anak berkembang sesuai dengan usia dantahapan perkembangan anak. Kegiatan yang menarik dan sesuai usia anak diperlukan dalam mendukung proses perkembangan kemampuan anak. Dalam penelitian ini menggunakan metode bercerita dengan aplikasi microsoft power point. Kegiatan bercerita menggunakan media power point yang dilakukan dengan tahapan meliputi; (1) membuat perencanaan pembelajaran harian sesuai tujuan pembelajaran, (2) membuat desain pembelajaran menggunakan power point interaktif yang inovati, (3) membuat isi cerita dalam power point interaktif sesuai karakteristik anak usia 4-5 tahun yang terarah, jelas, dan menyenangkan, (4) menggunakan musik dalam cerita power point agar menarik perhatian anak, (5) sosialisasi penggunaan power point dalam kegiatan bercerita bersama guru dan orangtua, (6) pelaksanaan kegiatan pembelajaran dilakukan online bersama orangtua atau wali murid dengan tetap menjalin komunikasi dengan guru di sekolah, (7) anak diberikan kesempatan 
untuk memilih isi cerita, berdiskusi, dan menceritakan kembali cerita yang sudah anak lihat dan dengarkan.

Hasil kemampuan berbicara anak kelompok A yang dilakukan pada saat penelitian menunjukkan peningkatan dan ketercapaian skor sesuai kriteria keberhasilan yaitu rata-rata tingkat kemampuan berbicara anak TK A sebesar 80,30 \% dari keseluruhan indikator. Indikator pencapaian kemampuan berbicara anak usia 4-5 tahun meliputi: Anak mampu mengucapkan kalimat yang lebih kompleks lebih dari lima kata, Anak mampu berbicara dengan kalimat yang sudah dipahami orang dewasa, Anak sudah bisa mengubah intonasi suara bisa semakin keras dan lembut sesuai situasi yang ada di sekitar anak, Anak mampu memberikan pertanyaan, Anak sudah dapat menjawab pertanyaan dengan tepat, dan anak mampu menceritakan kembali cerita yang didengarkan. Hasil individu pada setiap anak menunjukkan seluruh anak masuk dalam kategori berkembang sesuai harapan dan berkembang sangat baik. Berdasarkan data dari pra penelitian sampai siklus kedua menunjukkan kemampuan berbicara anak usia 4-5 tahun mengalami peningkatan. Hal ini membuktikan bahwa penggunaan media power point interaktif dapat meningkatkan kemampuan berbicara anak dalam pembelajaran online di masa pandemik.

\section{DAFTAR PUSTAKA}

Anggraeni, R. N., Fakhriyah, F., \& Ahsin, M. N. (2021). Peran orang tua sebagai fasilitator anak dalam proses pembelajaran online di rumah. Jurnal Ilmiah Pendidikan Dasar, 8(2), 105. https://doi.org/10.30659/pendas.8.2.105-117

Aprinawati, I. (2017). Penggunaan Media Gambar Seri Untuk Meningkatkan Kemampuan Berbicara Anak Usia Dini. Jurnal Obsesi : Jurnal Pendidikan Anak Usia Dini, 1(1), 72. https://doi.org/10.31004/obsesi.v1i1.33

Armelia Nungki Nurbani, \& Natalia Christina Sugiyanto. (2021). Powerpoint Sebagai Media Pembelajaran Daring Untuk Keterampilan Menyimak Siswa Usia Dini. Kanigara, 1(1), 62-72. https://doi.org/10.36456/kanigara.v1i1.3159

Fauziddin, M. (2017). Upaya Peningkatan Kemampuan Bahasa Anak Usia 4-5 Tahun melalui Kegiatan Menceritakan Kembali Isi Cerita di Kelompok Bermain Aisyiyah 
Gobah Kecamatan Tambang. Jurnal Obsesi : Jurnal Pendidikan Anak Usia Dini, 1(1), 42-51. https://doi.org/10.31004/obsesi.v1i1.30

Herliandry, L. D., Nurhasanah, N., Suban, M. E., \& Kuswanto, H. (2020). Pembelajaran Pada Masa Pandemi Covid-19. JTP - Jurnal Teknologi Pendidikan, 22(1), 65-70. https://doi.org/10.21009/jtp.v22i1.15286

Hodijah, S. (2016). Upaya Meningkatkan Keterampilan Berbicara Anak Melalui Metode Bermain Peran. Metodi Didaktik, 10(2), 1-69. https://doi.org/https://doi.org/10.17509/md.v10i2.3182

Jailani, M. S. (2014). Teori Pendidikan Keluarga dan Tanggung Jawab Orang Tua dalam Pendidikan Anak Usia Dini. Nadwa, 8(2), 245. https://doi.org/10.21580/nw.2014.8.2.580

Karlina, D. N., Ayu, W. A., \& Soesilo, T. D. (2018). Meningkatkan Kemampuan Berbicara Anak Usia 5-6 Tahun Melalui Digital Storytelling Di TK Apple Kids Salatiga. Jurnal Pendidikan Usia Dini, 12, 1-11. https://doi.org/https://doi.org/10.21009//JPUD.121.01 Latif, M. (2013). Orientasi Pendidikan Anak Usia Dini. Kencana.

Luqman, F., Ariyanto, T., \& Tanto, O. D. (2021). The Effectiveness of Power PointAssisted Picture Books on Receptive Language Development in Early Childhood. 3(2), 100-109. https://doi.org/10.33086/cej.v3i2.2103

Muhiyatul Huliyah. (2016). Hakikat pendidikan anak usia dini jalur pendidikan informal. Pendidikan Guru Raudlatul Athfal, 1(1), 61-62.

Munasti, K. (2021). Respon Penggunaan Media Power Point Berbasis Interaktif untuk Anak Usia Dini di Era Pandemi. Jurnal Obsesi : Jurnal Pendidikan Anak Usia Dini, 6(2), 876-885. https://doi.org/10.31004/obsesi.v6i2.1567

Mursid. (2015). Belajar dan Pembelajaran. PT Remaja Rosdakarya.

Nurdin, N., \& Anhusadar, L. (2020). Efektivitas Pembelajaran Online Pendidik PAUD di Tengah Pandemi Covid 19. Jurnal Obsesi : Jurnal Pendidikan Anak Usia Dini, 5(1), 686. https://doi.org/10.31004/obsesi.v5i1.699

Purwanto, W., \& W, E. T. D. R. W. (2016). Penggunaan Model Problem Based Learning Dengan Media Powerpoint Untuk Meningkatkan Minat Belajar Siswa. Jurnal 
Pendidikan: Teori, Penelitian, \& Pengembangan, 1700-1705.

https://doi.org/http://dx.doi.org/10.17977/jp.v1i9.6721

Rosalina, A., Widiasari, Y., \& Hapsari, M. I. (2010). Peranan Orangtua Dalam Dongeng

Sebelum Tidur Untuk Optimalisasi Kemampuan Berkomunikasi Anak Usia Dini.

Psycho Idea, 81-92.

Sablez, L., \& Pransiska, R. (2020). Analisis Pengaruh Mendongeng terhadap Kemampuan

Berbicara Anak Usia Dini. Jurnal Pendidikan Tambusai, 4, 3550-3557.

Sholiha, A. A., Darmiyanti, A., \& Riana, N. (2021). Meningkatkan Keterampilan Berbicara Anak Usia 4-5 Tahun Melalui Media Buku Bergambar Di TK Al-Anhar Karawang. Peteka Jurnal Penelitian Tindakan Kelas Dan Pengembangan Pembelajaran, 4, 311322.

Sintia, N., Kuswanto, C. W., \& Meriyati, M. (2019). Meningkatkan Kemampuan Sosial Anak Usia Dini dengan Model Outbound. Jurnal CARE (Children Advisory Research and Education), 6(2), 1-10. http://ejournal.unipma.ac.id/index.php/JPAUD/article/download/3939/2034

Wibowo, G. V., \& Suyadi, S. (2021). Penerapan Permainan Bahasa Guessing Games Berbasis Powerpoint Dalam Meningkatkan Keterampilan Berbicara Anak Usia Dini. Cakrawala Dini: Jurnal Pendidikan Anak Usia Dini, 12(1), 7-18. https://doi.org/10.17509/cd.v12i1.31060 